\title{
NOTES ON SOME APPARENTLY PREOCCUPIED ORNITHOLOGICAL GENERIC NAMES.
}

\section{By LEONHAIRD STEJNEGER.}

1.

Usually we find Fleming quoted as the author who established the genus Clangula. The genus is adopted by Boie, however, also in 1822, who quotes Cuvier as the authority for the name.* Where the latter has published it I am unable to find, and the earliest date to which I can trace it is 1819 , when it is applied by Leach for Anas glacialis Linn. alone, which species, therefore, must stand as the type, unless Cuvier's application of the name has the priority and a different type. As it seems that Harelda was not published until 1824, Clangula would have to supersede the latter. True, Gray (Hand-list III, p. 87) quotes " $\mathrm{Ha}$ relda Leach, 1816," but it is certainly not in this author's "Systematic List," nor can I discover any reference prior to 1824.

Should Harelda, after all, turn out to have the priority over "Clangula Leach, 1819," Clangula being a strict synonym of the former cannot be used for the golden-eyes in any case. As all the subsequent generic names bestowed upon the latter group are preoccupied, a new name has to be chosen, for which I propose

\section{+ Glaucionetta. $\dagger$}

SYNONYMY.

<1822.-Clangula Fleming, Philos. Zool., II, p. 260 (type A. clangula; nec Leach, 1819).

$=1829 .-$ Glaucion KaUp, Entw. Europ. Thierw., p. 53 (same type; nec OKen, 1816). <1858.-Bucephala BAIrD, B. North Am., p. 795 (type A. albeola; nec Bucephalus BAER, 1827).

The species are:

+ Glaucionetta clangula (Linn.).

+ Glaucionetta clangula americana (Bp.).

+Glaucionetta islandica (Gm.).

\section{2.}

The name which has been used as the generic term for the Spruce partridge and allied species is preoceupied in zoology, for as early as 1838 Canace was applied to a group of dipterous insects by Curtis, while

* In the first edition of the Règne Animal (1817), he only defined the group under the French appellation, "Les Garrots"; the word Clangula is not used generically or subgenerically.

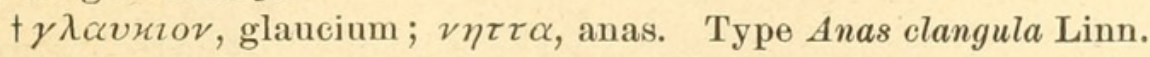


for the bird it was not proposed until 1852. This will necessitate the adoption of Elliot's Dendragapus, if we consider the Dusky Grouse congeneric with the Spruce Partridge. For the subgenus embracing the latter, a substitute for Canace is necessary, and to avoid too great dissimilarity it may be called Canachites.*

\section{THE CHACLACAYO TREPHINED SKULL.}

\section{By O'TIS T. TIASON.}

In the Journal of the Anthropological Institute of New York for 1871-'72, Mr. Squier describes a skull which was taken from an Inca cemetery in the valley of the Yucay, within 1 mile of the Baths of the Incas. This skull is figured also in Mr. Squier's "Incidents of travel and exploration in the land of the Ineas." $\dagger$ It has a square perforation on the left frontal prominence, made by the intersection of four furrows, cut probably with a stone implement. "In 1875, Mr. Henry Gilman, of Detroit, published in the American Naturalist $\ddagger$ a description of ten or fifteen skulls obtained from mounds on Sable River, Lake Huron, and two fragments from Grape Mound, Rouge River, Michigan." Each of these skulls was perforated at the vertex, evidently done by boring with a rude, probably stone instrument, varying in size (in some in. stances having a diameter one-third of an inch; in others of one-half an inch, and flaring at the surface).ई

In August, 1873, M. Prunieres made a communication, at the Lyons meeting of the French Association for the Advancement of Science, on cranial amulets.\| These amulets are roundish pieces of the human skull, some of them evidently taken out long enough before the death of the individual to allow a certain degree of healing.

In 1877 Dr. Paul Broca published an article in the Revue d'Anthro. pologie on the trephining of the skull and cranial amulets in the Neo. lithic period.甲 Between 1877 and 1882 several scattered communications were made upon the same subject before different societies in Europe. Dr. Robert Fletcher, of Washington, from whom most of this historical matter is taken, published in the fifth volume of Major Powell's Con

*Deriv., $\varkappa \alpha v \propto \chi \varepsilon \omega$, to be noisy. Type, Tetrao canadensis Linn.

†Peru. Incidents of travel and exploration in the land of the Incas. By E. George Squier. New York. Harper's, 1877, p. 456; Appendix A, 577-580.

$\ddagger$ American Naturalist, Salem, 1875, IX, 73.

§ Fletcher. "Prehistoric Trephining," 24; also Proceedings Am. Assoc., 24th meeting, pp. 316-331, and ibid., Nashville meeting, 187\%, 335-339, both quoted by Dr. Fletcher. See also Holbrook in American Naturalist, 1877, XI, 688.

$\|$ Association Française pour l'Avancement des Sciences. Compte rendu $2^{\text {me }}$ session. Lyon, 1873; Paris, 1874; p. 703. Also Bull. Soc. d'Anthrop. de Paris, 1874, 2 s., IX, 185-205.

T Sur la trépanation du crâne, et les amulettes crânieṇnes à l'époque néolithique, par Paul Broca. Paris, 1877; also, Rev. d'Anthrop., Paris, 1877, VI, 1-42, 193-225; also, Congrès d'Anthrop. et d'Archéol. prehist., Buda-Pesth, 1876, 101-192. 


\section{$2 \mathrm{BHL}$ Biodiversity Heritage Library}

Stejneger, Leonhard. 1885. "Notes on some apparently preoccupied ornithological generic names." Proceedings of the United States National Museum 8(530), 409-410. https://doi.org/10.5479/si.00963801.530.409.

View This Item Online: https://www.biodiversitylibrary.org/item/52770

DOI: https://doi.org/10.5479/si.00963801.530.409

Permalink: https://www.biodiversitylibrary.org/partpdf/51006

\section{Holding Institution}

Smithsonian Libraries

\section{Sponsored by}

Smithsonian

\section{Copyright \& Reuse}

Copyright Status: Public domain. The BHL considers that this work is no longer under copyright protection.

This document was created from content at the Biodiversity Heritage Library, the world's largest open access digital library for biodiversity literature and archives. Visit BHL at https://www.biodiversitylibrary.org. 